\title{
Streamflow of 2006 - Water Year Summary
}

\author{
U.S. Geological Survey \\ Reston, Virginia
}

January 2007

- National Overview

- $\underline{\text { Regional Patterns }}$

- Seasonal Characteristics

- High and Low Flows

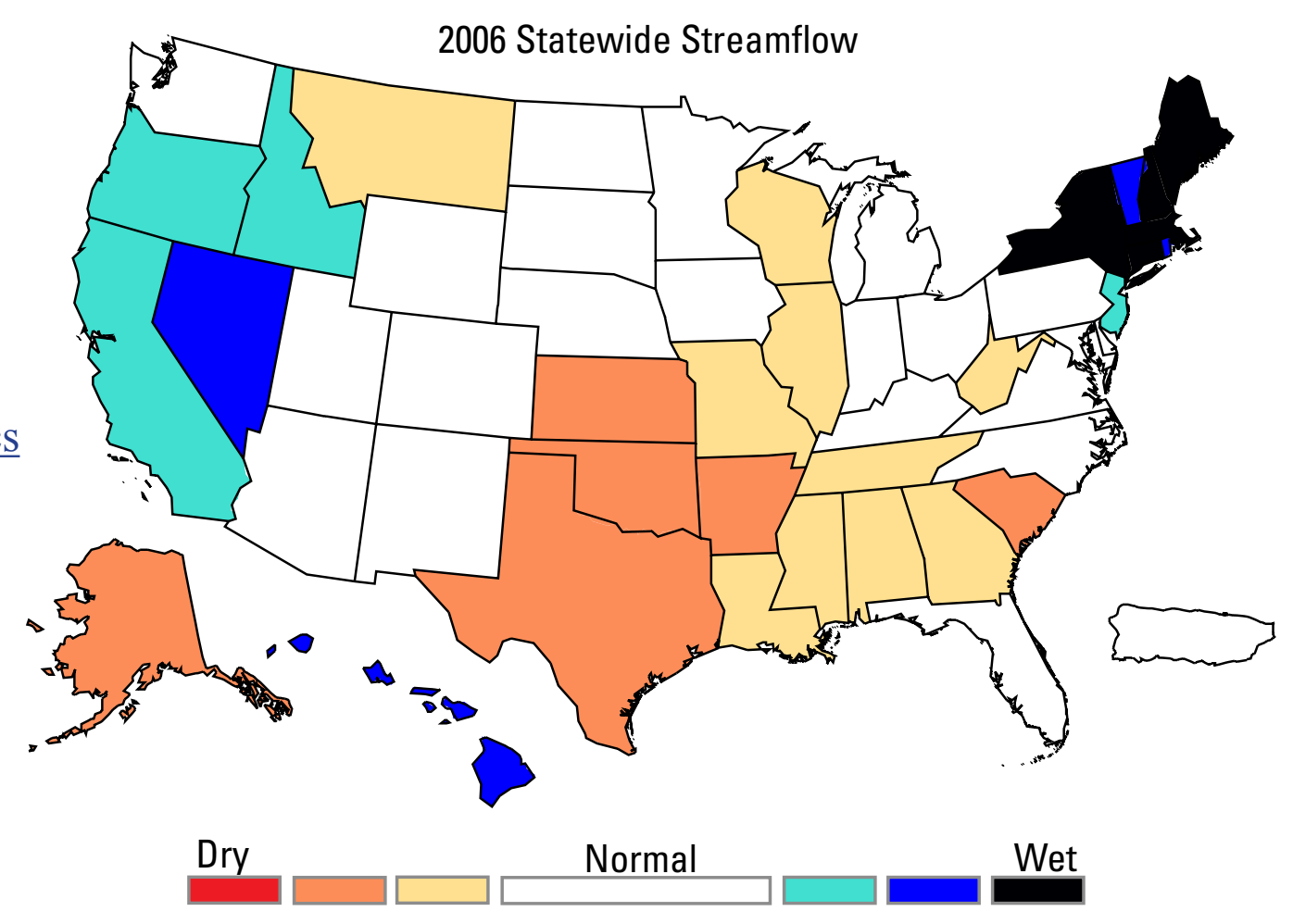

\section{Introduction}

The maps and graphs appearing in this summary describe streamflow conditions for water-year 2006 (October 1, 2005 to September 30, 2006) in the context of the 77-year period 1930-2006, unless otherwise noted. The illustrations are based on observed data from the U.S. Geological Survey's (USGS) National Streamflow Information Program. The period 1930-2006 was used because prior to 1930, the number of streamgages was too small to provide representative data for computing statistics for most regions of the country.

In the summary, reference is made to the term "runoff" which, as used here, expresses the depth to which a river basin, State, or other geographic area would be covered with water if all the streamflow within that area during a single year was uniformly distributed upon it. Runoff quantifies the magnitude of water flowing through the Nation's rivers and streams in measurement units that are comparable from one area to another. The runoff value for a geographic area is computed as the median runoff for all streamgages in that area. For example, the runoff value for a state is the median for all streamgages in that state, and the median for the Nation is the median value for all streamgages in the Nation.

Each of the maps and graphs below can be expanded to a larger view by clicking on the image. In all the graphics, a rank of 1 indicates the highest flow of all years analyzed. 


\section{National Overview}

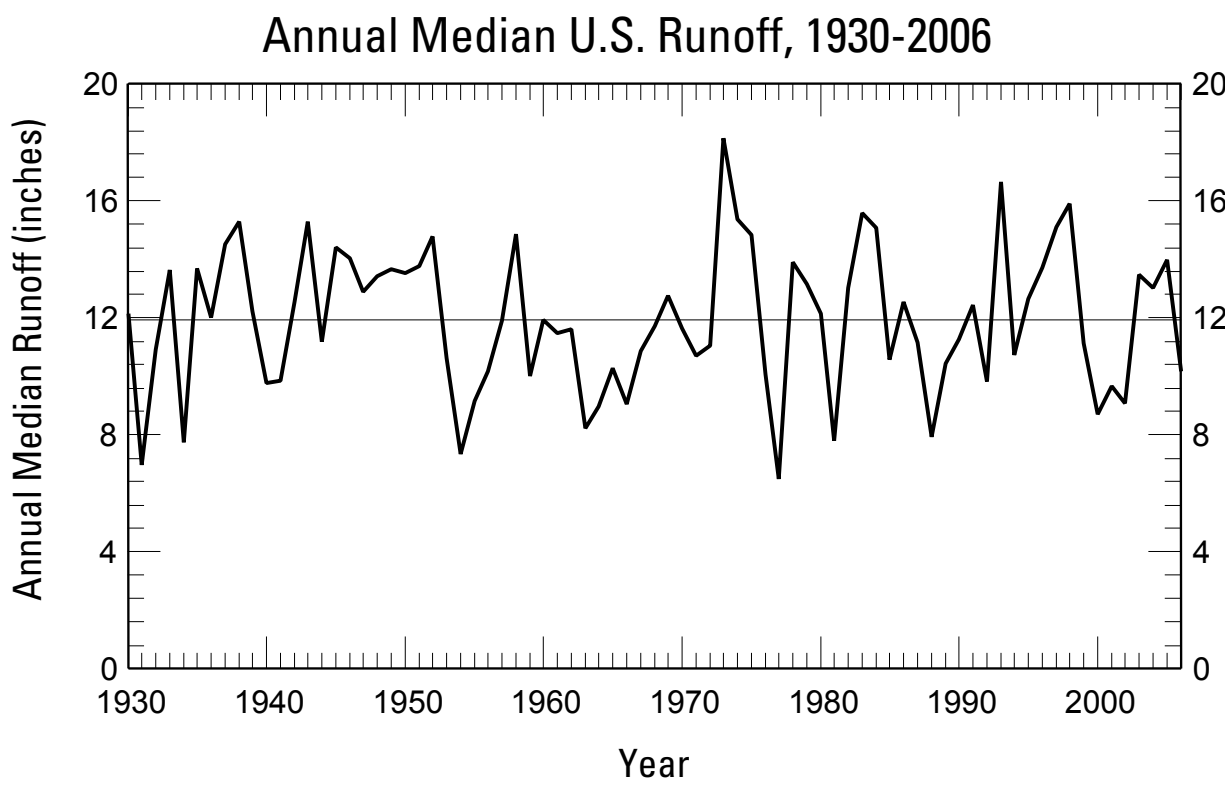

Runoff in the Nation's rivers and streams during 2006 (10.17 inches) was below the long-term annual median for the United States (11.93 inches). In 2006, the median runoff nationwide ranked 59 out of the 77 years in the period 1930-2006.

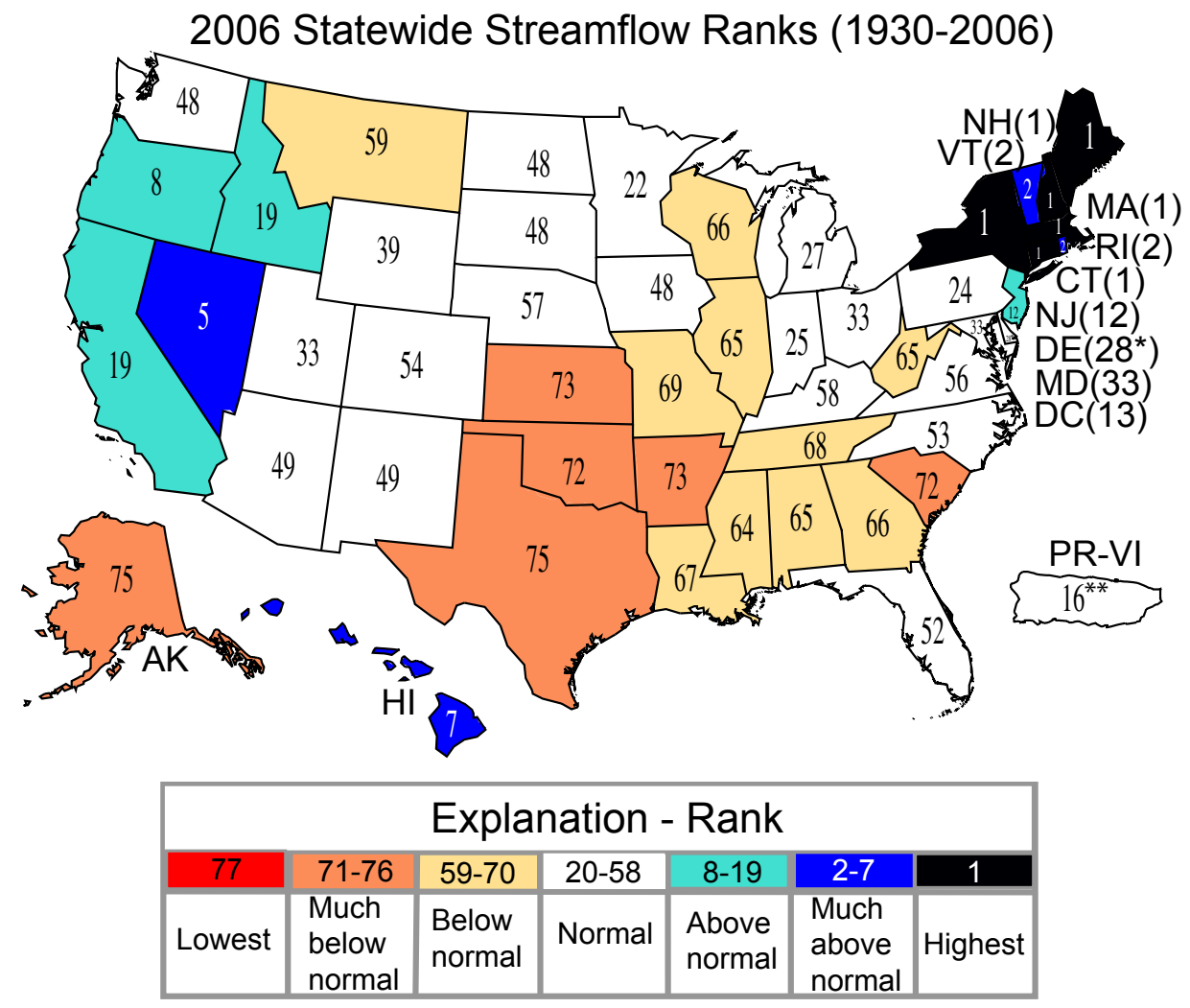

Above normal streamflow characterized most of the Pacific Coast states, the Northeast states, and Hawaii. Below normal streamflow was prevalent in the Southern Plains states and some Southeast states. Some Northeast states recorded record high flow conditions during 2006 compared to the historical period.

* Out of 68 years of historical data. ** Out of 63 years of historical data. 


\section{Regional Patterns}

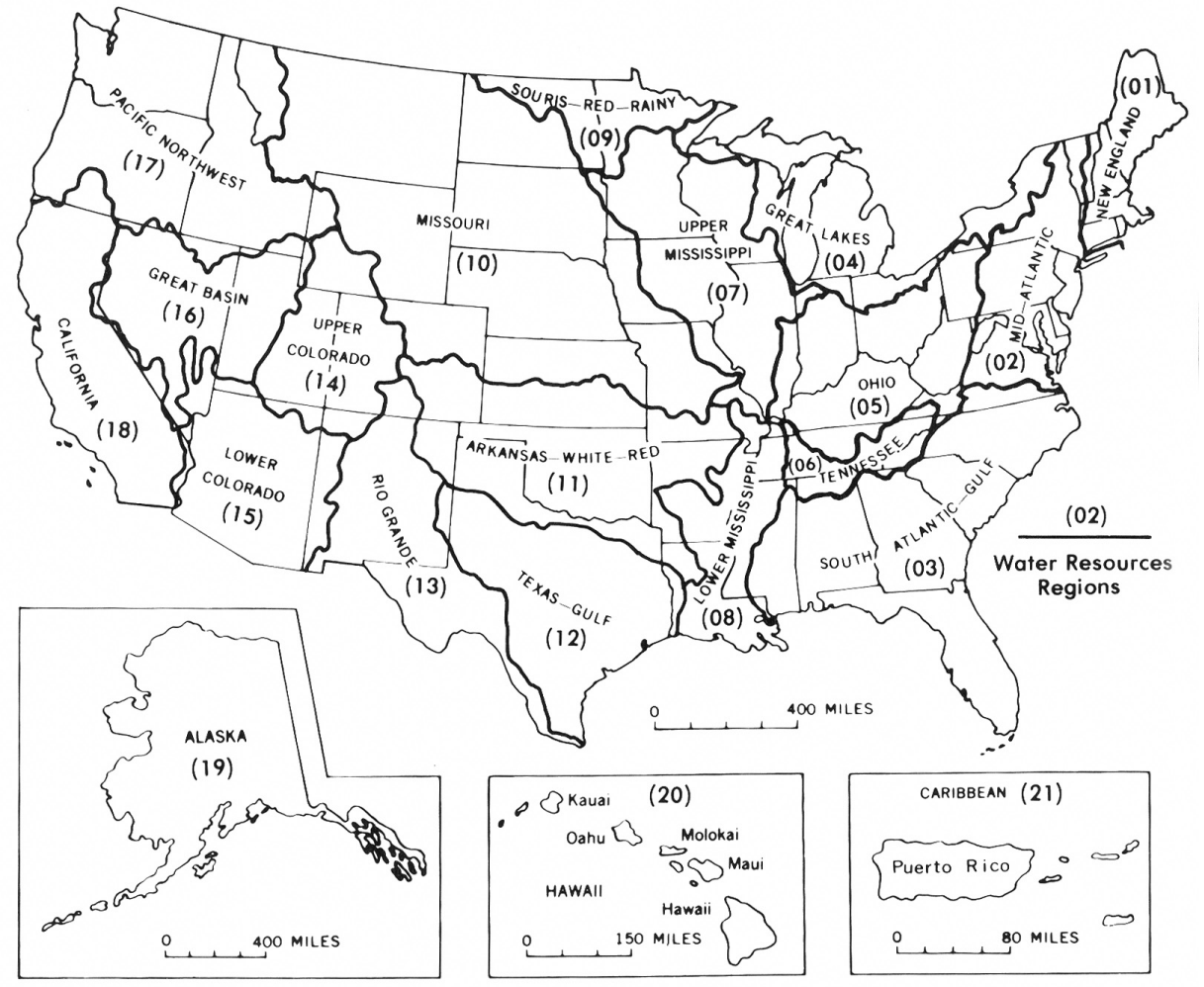

The United States (including Puerto Rico) is divided into 21 large drainages, or water resources regions. These hydrologic areas are based on surface topography and contain either the drainage area of a major river, such as the Columbia, the combined drainage areas of a series of rivers, such as the Texas-Gulf region which includes a number of rivers draining into the Gulf of Mexico, or the area of an island or island group. Water resources regions provide a coherent, watershed-based framework for depicting streamflow variations.

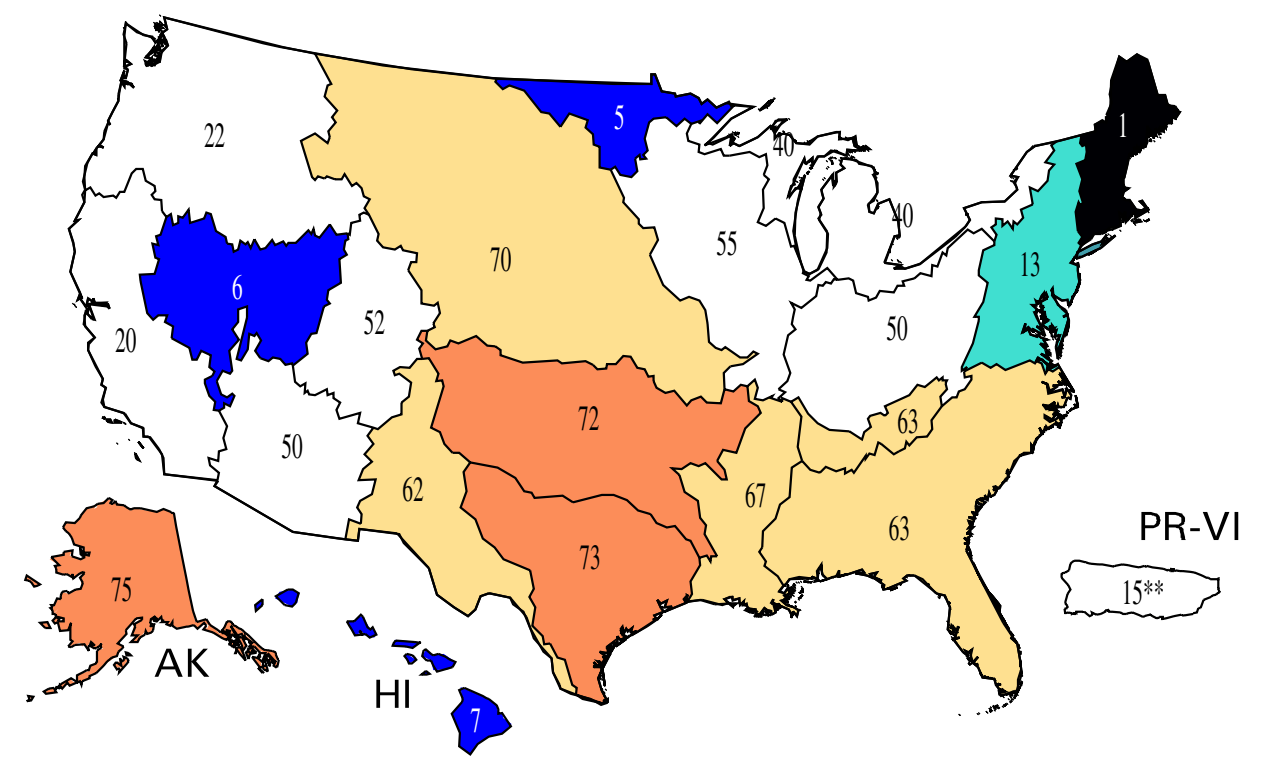

In 2006, notable regional streamflow differences were observed along the East Coast. The New England region, for example, recorded its highest annual flow since 1930, reflecting the record high precipitation that fell on this area during the year. The SouthAtlantic Gulf region, in contrast, was below normal. Below-normal conditions also were prevalent for most the Great Plains regions and Alaska.

** Out of 63 years of historical data.

\begin{tabular}{|c|c|c|c|c|c|c|}
\hline \multicolumn{7}{|c|}{ Explanation - Rank } \\
\hline 77 & $71-76$ & $59-70$ & $20-58$ & 8-19 & $2-7$ & 1 \\
\hline Lowest & $\begin{array}{l}\text { Much } \\
\text { below } \\
\text { normal }\end{array}$ & $\begin{array}{l}\text { Below } \\
\text { normal }\end{array}$ & Normal & $\begin{array}{l}\text { Above } \\
\text { normal }\end{array}$ & $\begin{array}{l}\text { Much } \\
\text { above } \\
\text { normal }\end{array}$ & Highest \\
\hline
\end{tabular}




\section{Seasonal Characteristics}

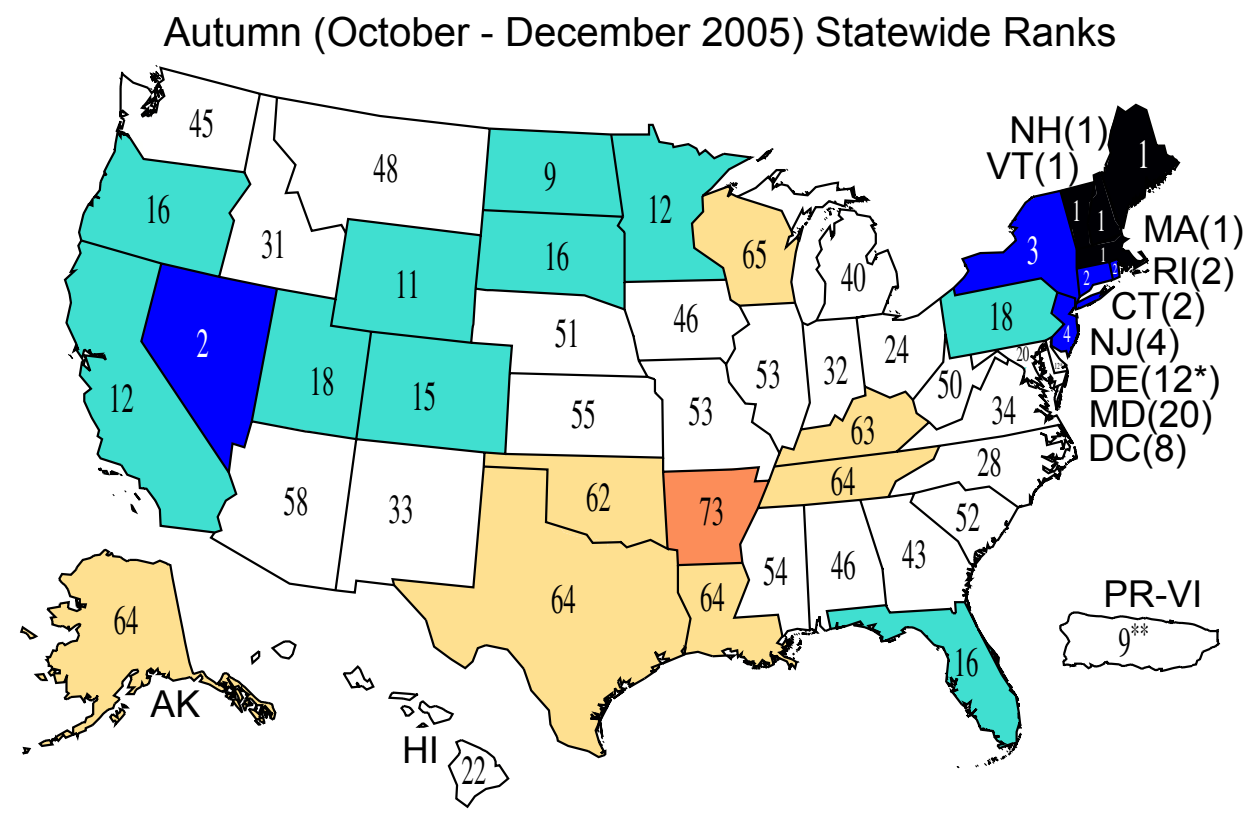

Autumn season (Oct-Dec) streamflow was normal nationwide (32nd highest autumn flows in 77 years). Four states reported new record high autumn streamflow: Maine, Vermont, New Hampshire, and Massachusetts.

* Out of 68 years of historical data. ** Out of 63 years of historical data.

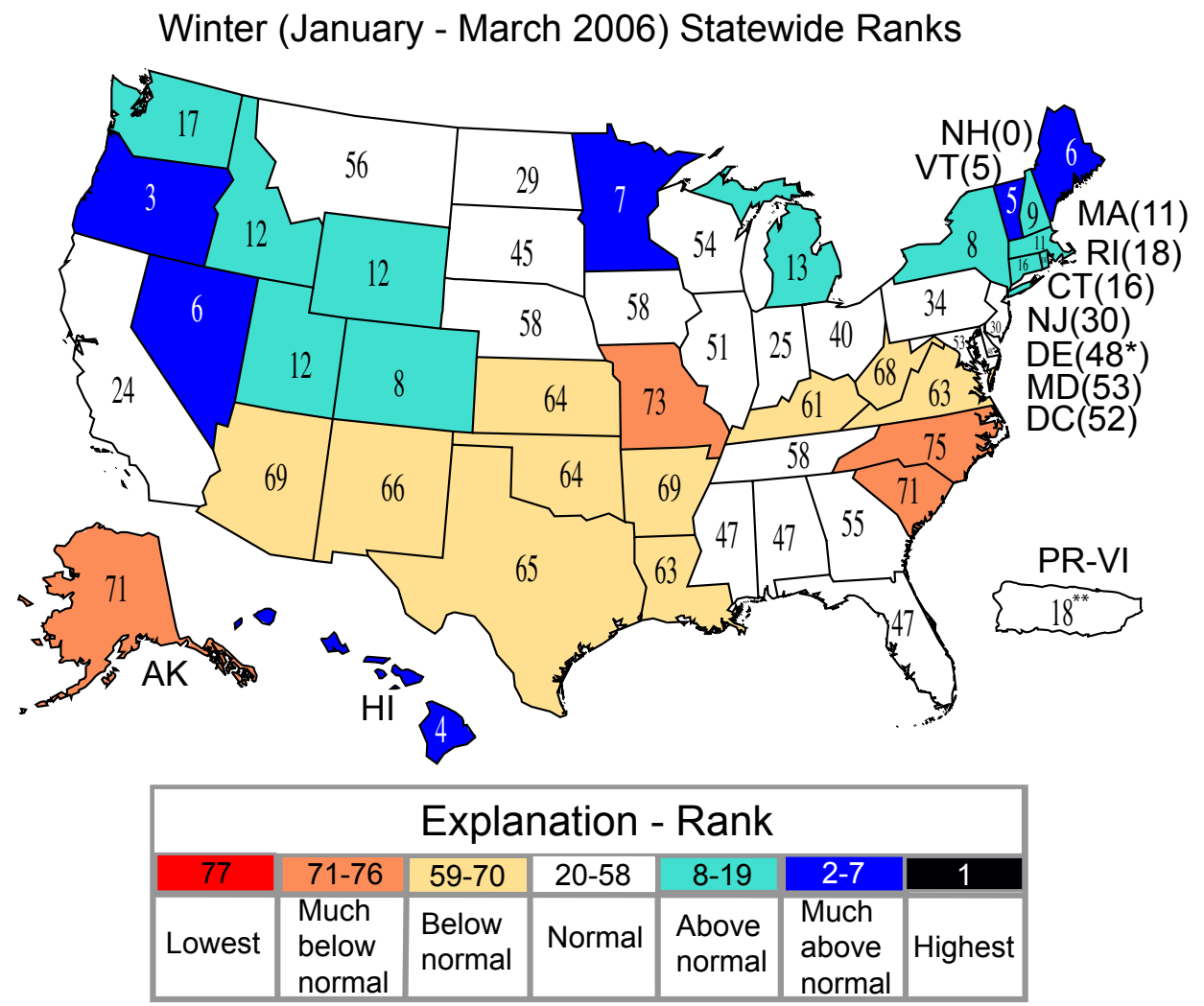

Winter season (January-March) streamflow was at the low end of normal for the Nation, ranking as the 53rd highest in 77 years. Normal or above normal streamflow occurred across the northern half of the conterminous U.S. and Hawaii, while below-normal flow characterized most of the southern states and Alaska.

* Out of 68 years of historical data. ** Out of 63 years of historical data. 


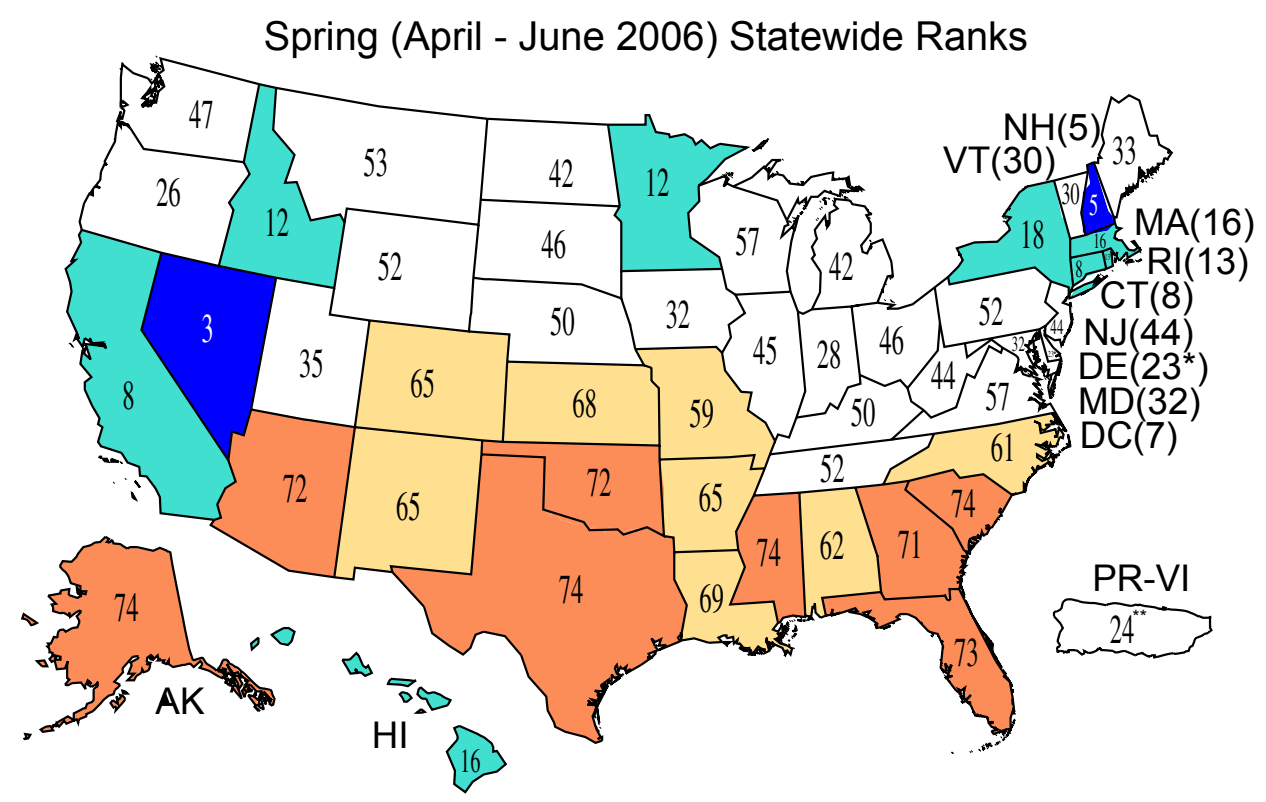

Spring season (April-June) streamflow was at the low end of normal (56th highest in 77 years) nationwide. Similar to the Winter season, Spring flows were normal or above normal in the northern states and below normal in the southern states and Alaska.

* Out of 68 years of historical data. ** Out of 63 years of historical data.

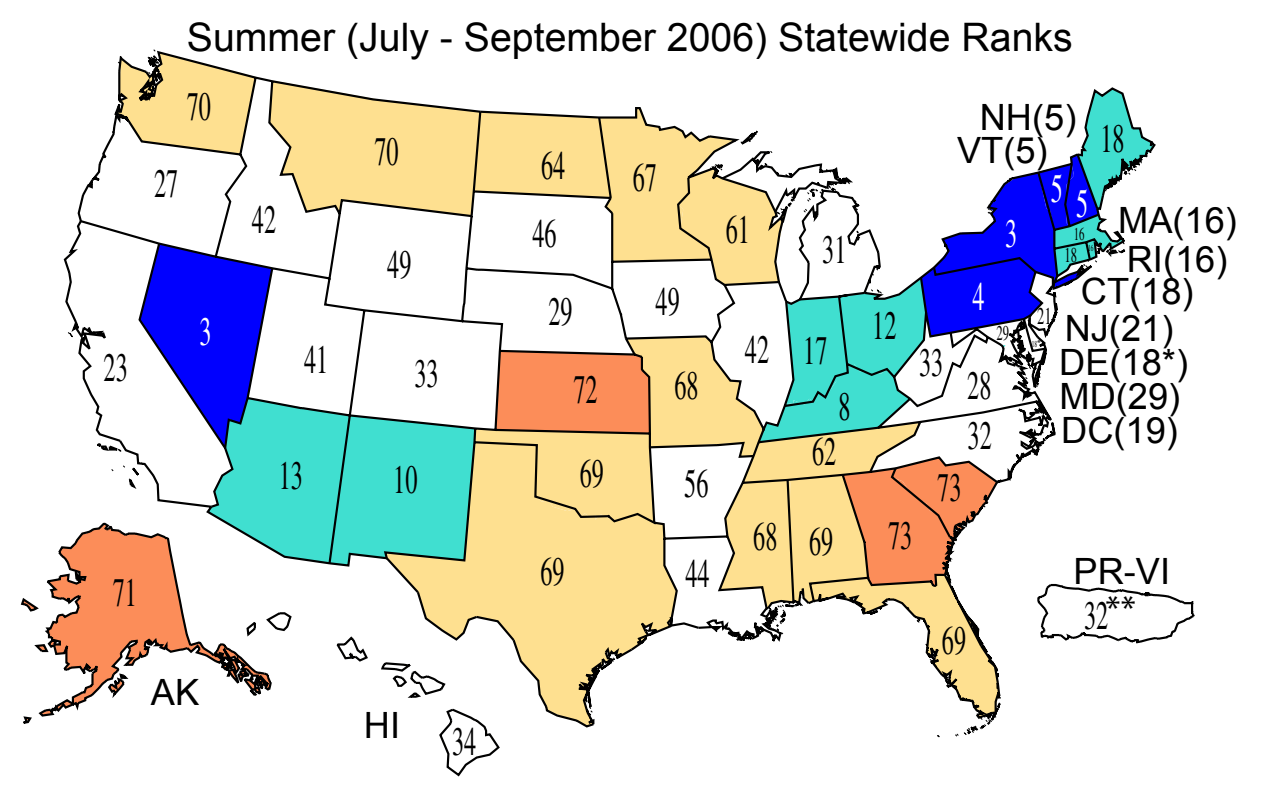

Summer season (July-September) streamflow was in the normal range for the U.S., ranking 28th out of 77 summer seasons in the record.

* Out of 68 years of historical data. ** Out of 63 years of historical data.

\begin{tabular}{|c|c|c|c|c|c|c|}
\hline \multicolumn{7}{|c|}{ Explanation - Rank } \\
\hline 77 & $\begin{array}{c}71-76 \\
59-70\end{array}$ & $20-58$ & $8-19$ & $2-7$ & 1 \\
\hline Lowest & $\begin{array}{l}\text { Much } \\
\text { below } \\
\text { normal }\end{array}$ & $\begin{array}{l}\text { Below } \\
\text { normal }\end{array}$ & Normal & $\begin{array}{l}\text { Above } \\
\text { normal }\end{array}$ & $\begin{array}{l}\text { Much } \\
\text { above } \\
\text { normal }\end{array}$ & Highest \\
\hline
\end{tabular}




\section{High and Low Flows}

\section{Percentage of Streamgages With Very High and Very Low Monthly Streamflow}

October 1999 - September 2006

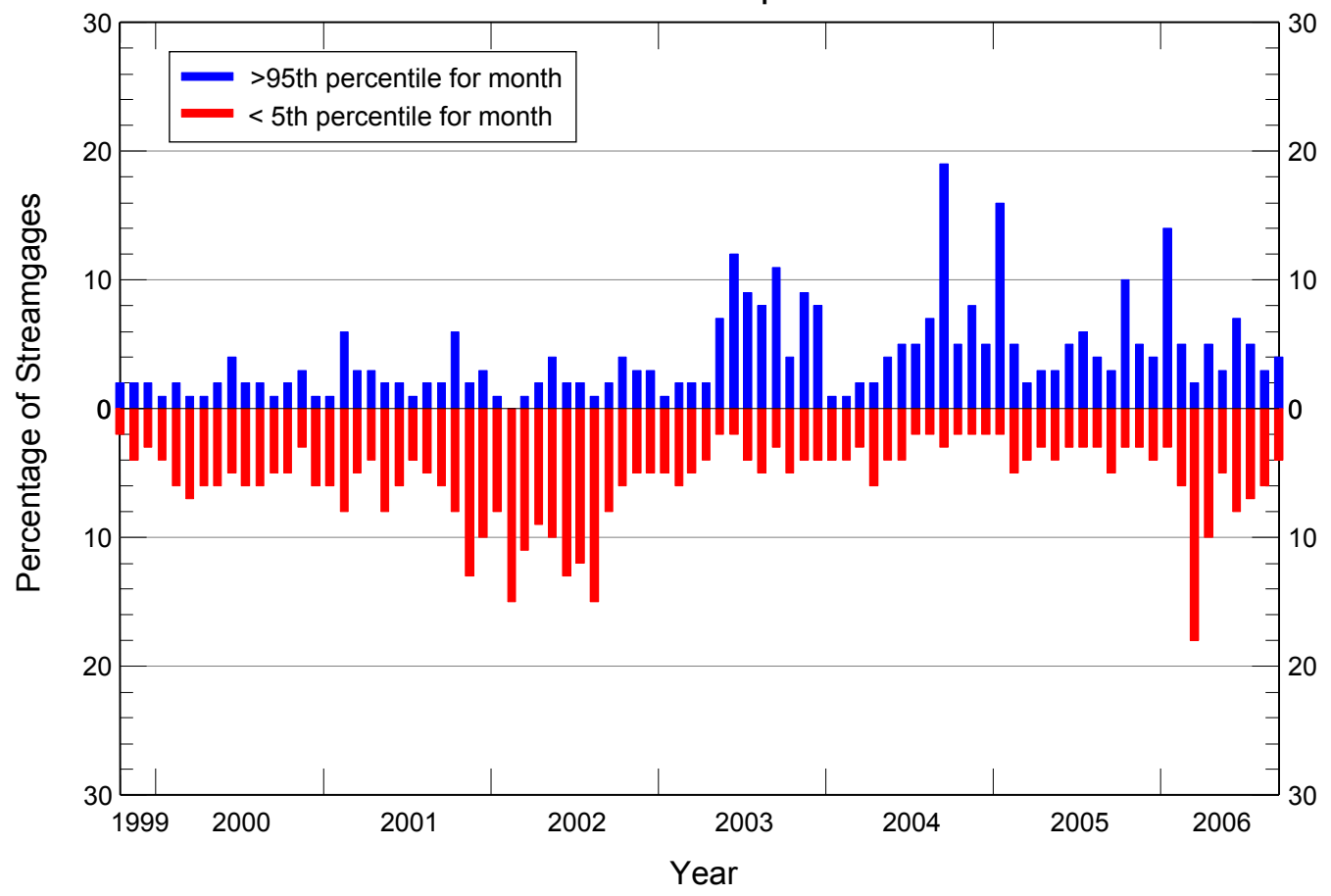

In any given month, on average, it is expected that five percent of the streamgages will experience very high $(>95$ th percentile) and very low ( $<5$ th percentile) average streamflow. During water year 2006, three months (October [2005], January, and June) had a greater number of streamgages than expected reporting very high flows (10,14, and 7 percent respectively). In contrast, 6 months during the water year had a greater number of streamgages than expected reporting very low flows (February-April and June-August). 
Percentage of Streamgages with Record High Daily Mean Flows 1950-2006

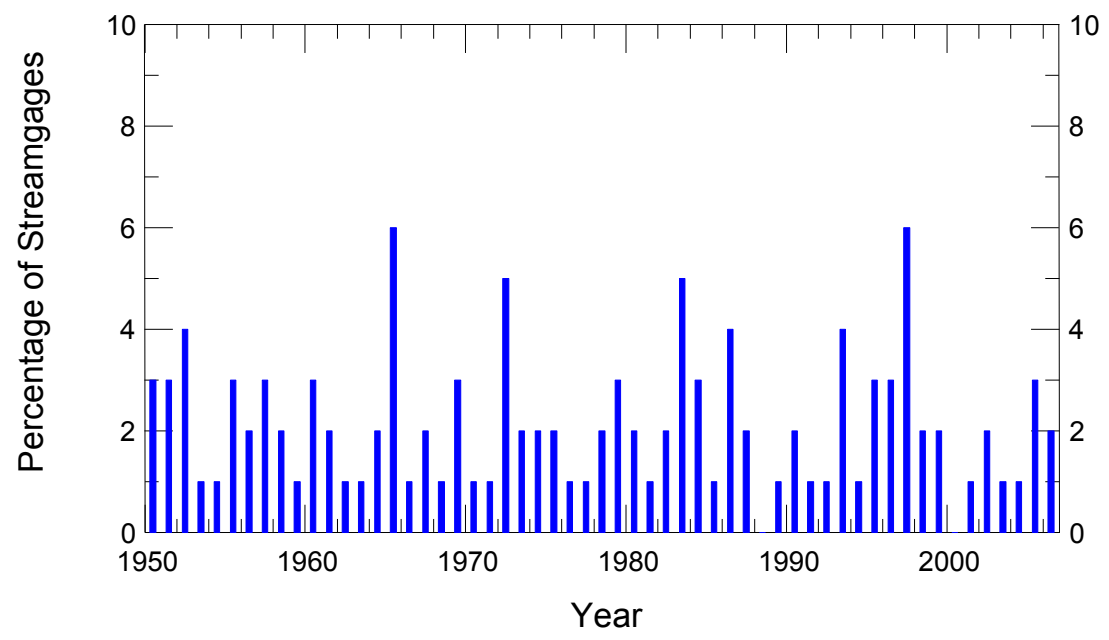

Percentage of Streamgages with Record 7-Day Low Flows 1950-2006

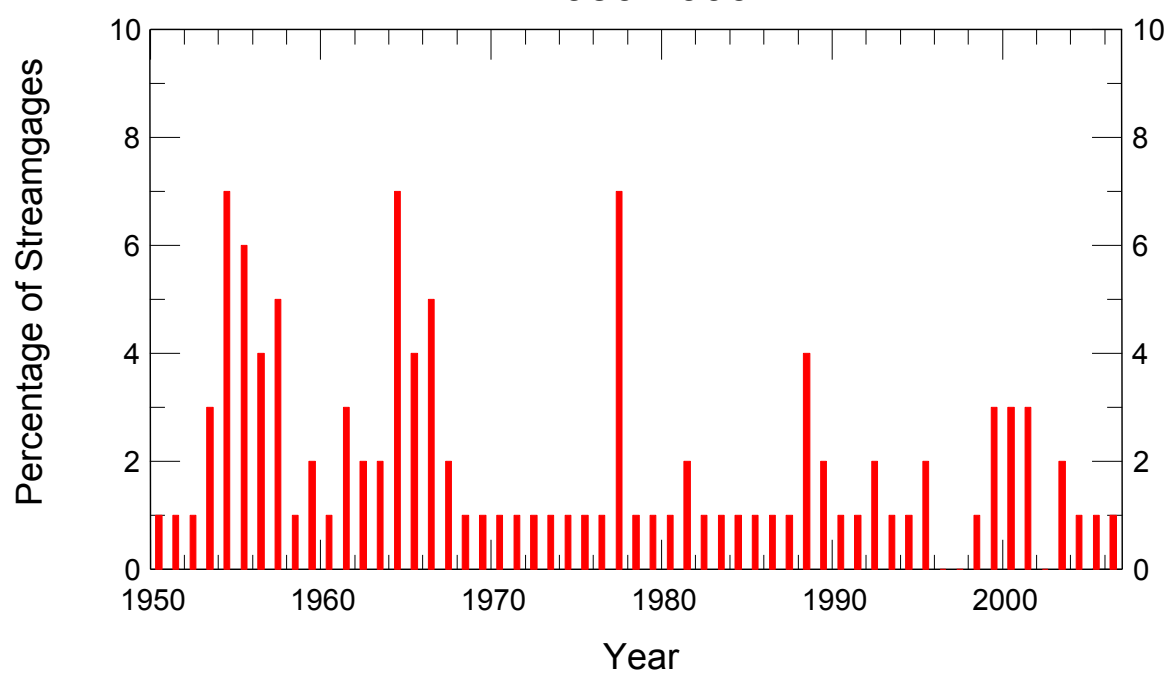

In 2006, two percent of USGS streamgages with at least 77 years of record reported new record high daily mean streamflow. Since 1950 , the largest number of streamgages reporting new record highs in any one year was six percent, which occurred in both 1965 and 1997.
The 7-day low flow is defined as the lowest average streamflow to occur on seven consecutive days in a year. The number of new all-time record 7-day low streamflows that have been set annually since 1999 (the year when the current period of widespread drought began in the U.S.) has been well-below the number of records set during previous multi-year drought periods, such as those of the 1950s and 1960s. In 1954, 1964, and 1977, for example, seven percent of the streamgages set new all-time record 7-day low flows. 


\section{Additional Information}

The USGS operates a network of approximately 7,400 streamgages nationwide. Current information derived from these stations is available on the web at http://water.usgs.gov/ waterwatch. Tables of data that summarize historical streamflow conditions by State, beginning in the year 1900, can be accessed at http://water.usgs.gov/waterwatch/? $m=$ statesum. These tables are updated every few months to reflect the most current streamflow data.

The streamflow information used to prepare this summary is also used for water management, monitoring floods and droughts, bridge design, and for many recreational activities. To obtain real-time and archived streamflow data and information, visit http://water.usgs.gov/nwis. Although the national streamgage network is operated primarily by the USGS, it is funded by a partnership of 850 agencies at the Federal, State, Tribal, and local levels. For more information about the streamgage network, see http://water.usgs.gov/nsip/.

This document is available online at http://water.usgs.gov/ waterwatch/2006summary/.
By Xiaodong Jian, David M. Wolock, and Harry F. Lins

For additional information, contact: Harry Lins U.S. Geological Survey 415 National Center Reston, VA 20192 Email: hlins@usgs.gov

\section{Accessibility FOIA Privacy Policies and Notices}

$\underline{\text { U.S. Department of the Interior }}$ U.S. Geological Survey

URL: http://water.usgs.gov/waterwatch/

Page Contact Information: Office of Surface Water 